Kansas State University Libraries

New Prairie Press

Academic Chairpersons Conference

32nd Academic Chairpersons Conference,

Proceedings

Austin, TX

\title{
Academic Leaders Shaping Work-Life Culture
}

\author{
Laura Bryan \\ University of Baltimore, LBryan@ubalt.edu \\ Cheryl Wilson \\ University of Baltimore, cwilson2@ubalt.edu
}

Follow this and additional works at: https://newprairiepress.org/accp

Part of the Educational Leadership Commons, Higher Education Administration Commons, and the Industrial and Organizational Psychology Commons

\section{Recommended Citation}

Bryan, Laura and Wilson, Cheryl (2015). "Academic Leaders Shaping Work-Life Culture," Academic Chairpersons Conference Proceedings. https://newprairiepress.org/accp/2015/Leadership/17

This Event is brought to you for free and open access by the Conferences at New Prairie Press. It has been accepted for inclusion in Academic Chairpersons Conference Proceedings by an authorized administrator of New Prairie Press. For more information, please contact cads@k-state.edu. 
1) Primary presenter information and curriculum vitae or short biographical sketch:

\section{Laura Koppes Bryan}

Laura Koppes Bryan is Dean of the Yale Gordon College of Arts and Sciences at the University of Baltimore (UB). Prior to UB, she was the Director and Professor of the School of Psychological and Behavioral Sciences, University of West Florida (UWF). At UWF, she founded the Center for Applied Psychology and the Center on Aging, and was also the Special Assistant to the Provost for Strategic Planning and Resource Allocation and the Interim Director for the Women's Studies Program. Before UWF, she was Director of Work-Life at the University of Kentucky. Dr. Bryan earned her BS in Psychology and her $\mathrm{MA}$ and $\mathrm{PhD}$ in industrial and organizational psychology from The Ohio State University. She is the author of Shaping Work-Life Culture in Higher Education (Routledge, 2014).

\section{Cheryl A. Wilson}

Cheryl A. Wilson is Associate Professor of English and Chair of the Klein Family School of Communications Design at the University of Baltimore. She is the author of Fashioning the Silver Fork Novel (Pickering \& Chatto, 2012); Literature and Dance in Nineteenth-Century Britain (Cambridge UP, 2009) and a contributor to Shaping Work-Life Culture in Higher Education (Routledge, 2014).

\section{2) Additional presenter information (if applicable):}

3) Title of presentation: Academic Leaders Shaping Work-Life Culture

4) Abstract: Presenters and participants will discuss emerging strategies and best practices available to chairs to support the creation of departmental cultures that are friendly and responsive to the work-life needs of faculty and staff.

5) Keywords: Work-Life, faculty, departmental culture, academic leadership, career flexibility

6) Presentation topic themes: pressing issues and trends in higher education, leadership and management.

7) Target audience: All Department Chairs as well as other University administrators

8) Type of presentation: best practice presentation

9) Objective(s) of the presentation: Participants will:

a) gain a basic understanding of organizational cultures and the importance of work-life research to higher education

b) increase knowledge of strategies and practices implemented by academic leaders

c) develop specific strategies for their own academic departments/units

10) Description of the session (300 -500 words): 
In the Summer of 2013, the American Council on Education (ACE) announced a challenge to Presidents of higher education institutions to become involved with a national campaign promoting faculty career flexibility. College and university leaders were invited to sign a statement of support for expanding workplace flexibility that includes the following conviction: "We believe that supporting flexibility must become a core leadership competency to enable our faculty to meet the increasing demands of twenty-first century workplaces and to meet their personal and family responsibilities." ${ }^{\text {"i }}$ This recent challenge is somewhat startling given that corporations have been responding to employees trying to balance work and family responsibilities (i.e., work-life) for more than forty years. ${ }^{i i}$ Corporate leaders have recognized that demographic changes over the past four decades, such as an increase in the number of women working full time, rise of dual career and single-parent families, and the expansion of an aging population, have resulted in an increasingly diverse workforce and a greater potential for individuals to face work-life conflict and stress. ${ }^{\text {iii }}$

Colleges and universities are not immune to demographic and societal changes; thus, one of the most critical issues facing higher education today is the changing workforce in the academy. Giving birth, adopting a child, and caring for children are the primary reasons that women faculty, in particular, leave academe or do not achieve tenure and/or promotion. As men become more engaged with child caregiving, they, too, have reported increased conflicts from managing faculty and family responsibilities. In addition, elder care is rapidly becoming a significant concern for both men and women.

For this seminar, we will invite Chairs to consider work-life scenarios encountered at the department level. To frame and contextualize this discussion, we will present results of an extensive literature review of research studies examining the role of leaders in fostering a work-life culture, as well as interviews with 21 academic leaders who were identified by their colleagues as being worklife friendly. From this research, we identified leader strategies to shape cultures responsive to the work-life needs of faculty and staff. The institutions discussed here vary in terms of their mission, size, population, affiliation, and geography, ranging from small private schools to large state institutions. Nonetheless, the experiences shared by the contributors share a few common themes: communication, flexibility, and commitment. Following the discussion of research and best practices, we will share and several work-life scenarios and strategies and best practices through which Chairs can support the work-life needs of their faculty, staff, and students.

\footnotetext{
${ }^{\mathrm{i}}$ American Council on Education. (2013). National challenge for higher education: Retaining a $21^{\text {st }}$ century workforce. Retrieved from http://www.acenet/edu/leadership/programs/Pages?NationalChallenge.aspx. ii Alliance for Work-Life Progress. (2012). Work-life history and timeline. Session at the National WorkLife Summit, New Orleans, LA.

iii Brough, P., \& Kelling, A. (2002). Women, work \& well being: The influence of work-family and family-work conflict. New Zealand Journal of Psychology, 31(1), 29-38; Bogese, C., Schneider, S. K., \& Koppes, L. L. (2010). Preferences for supervisor behaviors: The influence of gender and parenthood. Poster presented at the $56^{\text {th }}$ annual meeting of the Southeastern Psychological Association, Chattanooga, TN.; Hobson, C. J., Delunas, L. \& Kesic, D. K. (2001). Compelling evidence of the need for corporate work/life balance initiatives: results from a national survey of stressful life-events. Journal of Employment Counseling, 38(1), 38-44.
} 